\title{
Anti-bacterial activity of intermittent preventive treatment of malaria in pregnancy: comparative in vitro study of sulphadoxine-pyrimethamine, mefloquine, and azithromycin
}

\author{
Mesküre Capan ${ }^{1,2}$, Ghyslain Mombo-Ngoma ${ }^{1,2,3}$, Athanasios Makristathis ${ }^{4}$, Michael Ramharter ${ }^{1,2,5^{*}}$
}

\begin{abstract}
Background: Intermittent preventive treatment of malaria with sulphadoxine-pyrimethamine (SP) is recommended for the prevention of malaria in pregnancy in sub-Saharan Africa. Increasing drug resistance necessitates the urgent evaluation of alternative drugs. Currently, the most promising candidates in clinical development are mefloquine and azithromycin. Besides the anti-malarial activity, SP is also a potent antibiotic and incurs significant antimicrobial activity when given as IPTP - though systematic clinical evaluation of this action is still lacking.

Methods: In this study, the intrinsic anti-bacterial activity of mefloquine and azithromycin was assessed in comparison to sulphadoxine-pyrimethamine against bacterial pathogens with clinical importance in pregnancy in a standard microdilution assay.

Results: SP was highly active against Staphylococcus aureus and Streptococcus pneumoniae. All tested Gram-positive bacteria, except Enterococcus faecalis, were sensitive to azithromycin. Additionally, azithromycin was active against Neisseria gonorrhoeae. Mefloquine showed good activity against pneumococci but lower in vitro action against all other tested pathogens.

Conclusion: These data indicate important differences in the spectrum of anti-bacterial activity for the evaluated anti-malarial drugs. Given the large scale use of IPTp in Africa, the need for prospective clinical trials evaluating the impact of antibiotic activity of anti-malarials on maternal and foetal health and on the risk of promoting specific drug resistance of bacterial pathogens is discussed.
\end{abstract}

\section{Background}

Malaria in pregnancy is associated with low birth-weight [1-3], pre-term delivery [4] and maternal anaemia [5] and is therefore an important cause of maternal, perinatal, and neonatal morbidity and mortality in pregnancy and the puerperium in sub-Saharan Africa [6,7]. The World Health Organization recommends intermittent preventive treatment of malaria in pregnancy with sulphadoxine-pyrimethamine (SP-IPTp) in order to reduce adverse health outcomes for pregnant women and their offspring $[8,9]$. Curative doses of SP are administered during routine antenatal visits at least twice after the

\footnotetext{
* Correspondence: michael.ramharter@meduniwien.ac.at

${ }^{1}$ Institute for Tropical Medicine, University of Tübingen, Tübingen, Germany Full list of author information is available at the end of the article
}

first trimester in HIV negative and at least three times in HIV positive women. Due to rising drug resistance of Plasmodium falciparum against SP, potential alternative anti-malarial drugs have been proposed for future use as IPTp [10]. These compounds include amodiaquine, azithromycin, mefloquine, and combinations of these drugs with artemisinin derivatives or chloroquine [11,12].

Bacterial infections including sexually transmitted diseases, urinary tract infections, and group B streptococcal carriage are causes for considerable morbidity and mortality in pregnant women and the unborn child. In subSaharan Africa adequate diagnosis and treatment of these infections are often lacking. SP belongs to the class of anti-folates exerting considerable anti-microbial activity besides its anti-malarial activity. Anti-folate antibiotics 
show clinically important activity against Streptococcus pneumoniae, Staphylococcus aureus, Escherichia coli, and other pathogenic bacteria and are, therefore, used on a large scale for the treatment of urinary tract infections, skin and soft tissue infections, and in other indications $[13,14]$. Whereas mefloquine use is currently restricted to treating falciparum malaria, azithromycin is in use for the treatment of a variety of bacterial infections including respiratory tract infections and sexually transmitted diseases and it is under investigation for combination therapy of falciparum malaria $[15,16]$.

IPTp with a drug exerting anti-bacterial activity may, therefore, offer a significant additional public health benefit by providing treatment for undetected or previously untreated bacterial infections in pregnant women. Conversely, widespread use of antibiotics may increase the risk for the development of drug resistance leading to future difficulties in the clinical management of bacterial infections.

This study aimed to assess the anti-bacterial activity of SP, mefloquine and azithromycin - the most promising candidate drugs for the replacement of SP for IPTp [15] against common Gram-positive and Gram-negative bacteria in vitro.

\section{Methods}

The minimal inhibitory concentrations (MIC) of mefloquine, azithromycin, and SP was assessed against bacterial pathogens with medical importance during pregnancy. For this purpose, common bacterial pathogens causing urinary tract infections (Escherichia coli, Enterococcus faecalis), sexually transmitted diseases (Neisseria gonorrhoeae), skin and soft tissue infections (Staphylococcus aureus) and neonatal sepsis (Group B beta-haemolytic streptococci; i.e. Streptococcus agalactiae) were studied. Tested microorganisms consisted of clinical isolates and American Type Culture Collection (ATCC) strains as external controls. Bacteria were grown overnight at $37^{\circ} \mathrm{C}$ in Mueller Hinton broth with or without $2-5 \%$ horseblood. Neisseria gonorrhoeae was incubated overnight at $35^{\circ} \mathrm{C}$ in an atmosphere containing $5 \% \mathrm{CO}_{2}$ on New York City agar and chocolate agar.

All drugs were obtained from Sigma-Aldrich (Seelze, Germany) and were first dissolved and diluted to stock solutions. Further 1:2 dilutions of stock solutions were done with culture medium in order to achieve respective drug concentrations. Mueller Hinton broth medium was commercially prepared (Merck KGaA, Darmstadt, Germany). Fastidious broth medium was used for cultivation of $N$. gonorrhoeae and was prepared as described previously consisting of $35 \mathrm{~g}$ Columbia broth base, $5 \mathrm{~g}$ glucose, $5 \mathrm{~g}$ yeast extract, $2 \mathrm{~g}$ neopeptone, and $0.75 \mathrm{~g}$ agarose dissolved in $960 \mathrm{ml}$ of distilled water [17]. A total of $30 \mathrm{ml}$ haematin solution $(0.05 \%[\mathrm{wt} / \mathrm{vol}]$ in $0.1 \mathrm{M} \mathrm{NaOH})$ and $5 \mathrm{ml}$ Tween 80 (10\% [vol/vol]) was then added. The resultant broth was sterilized by autoclaving and $6 \mathrm{ml}$ of pyridoxal solution $(0.1 \%[\mathrm{wt} / \mathrm{vol}])$ and $1.5 \mathrm{ml}$ of NAD solution $(1 \% \mathrm{wt} / \mathrm{vol})$ were added.

\section{Determination of MICs}

MICs were determined by employing a standard microdilution assay following Clinical and Laboratory Standards Institute (CLSI) guidelines with fastidious broth medium and Mueller Hinton broth and a bacterial turbidity of $0.5 \mathrm{McF}$ arland. The final bacterial density was approximately $10^{5} \mathrm{CFU} / \mathrm{ml}$. The 96 -well plates were incubated for $24 \mathrm{~h}$ at $35^{\circ} \mathrm{C}$ in a moist atmosphere containing $5 \%$ $\mathrm{CO}_{2}$. Positive control wells contained microorganisms without antibiotics. All tests were performed in duplicate and MICs were reported as arithmetic means.

\section{Classifiction of anti-bacterial activity}

CLSI consensus cut off levels were used for the categorization of anti-bacterial activity. Azithromycin susceptibility was assessed using the following cut off levels for classification as sensitive, intermediate and resistant: $S$. aureus $\leq 2$ $\mu \mathrm{g} / \mathrm{ml},>2-<8 \mu \mathrm{g} / \mathrm{ml}, \geq 8 \mu \mathrm{g} / \mathrm{ml}$; S. pneumonia and $S$. agalactiae $\leq 0.5 \mu \mathrm{g} / \mathrm{ml},>0.5-<2 \mu \mathrm{g} / \mathrm{ml}, \geq 2 \mu \mathrm{g} / \mathrm{ml}$. In case of $N$. gonorrhoeae, due to a lack of CLSI recommendations, the European committee on anti-microbial susceptibility testing (EUCAST) definitions for azithromycin cut-off values $(\leq 0.25 \mu \mathrm{g} / \mathrm{ml} ;>0.25 \mu \mathrm{g} / \mathrm{ml}-\leq$ $0.5 \mu \mathrm{g} / \mathrm{ml} ;>0.5 \mu \mathrm{g} / \mathrm{ml}$ as sensitive, intermediate, resistant) were employed.

No break points are defined for the activity of azithromycin against E. coli and Enterococcus by CLSI and EUCAST. Cut off levels as proposed for $S$. aureus $(\leq 2 \mu \mathrm{g} / \mathrm{ml},>2-<8 \mu \mathrm{g} / \mathrm{ml}, \geq 8 \mu \mathrm{g} / \mathrm{ml}$ for susceptible, intermediate and resistant, respectively) were therefore used.

No recommendations are available for mefloquine and SP by CLSI or EUCAST and no previous publications on the interpretation of in vitro anti-bacterial activity of the two anti-malarial drugs were found. For the classification of SP activity - due to comparable anti-bacterial pharmacodynamics in the class of antifolate antibiotics and similar molecular weights for trimethoprim and pyrimethamine (290 and 249, respectively) - CLSI and EUCAST threshold levels of anti-bacterial activity were used as defined for trimethoprim-sulphamethoxazole. These definitions are based on trimethoprim drug concentrations and were employed for pyrimethamine to classify SP activity. The CLSI cut off levels for classification as sensitive, intermediate and resistant are the following: $S$. aureus and E.coli: $\leq 2 \mu \mathrm{g} / \mathrm{ml} ;>2-<4 \mu \mathrm{g} / \mathrm{ml} ; \geq 4 \mu \mathrm{g} / \mathrm{ml}$, S. pneumonia: $\leq 0.5 \mu \mathrm{g} / \mathrm{ml} ;>0.5-<4 \mu \mathrm{g} / \mathrm{ml} ; \geq 4 \mu \mathrm{g} /$ $\mathrm{ml}$. The EUCAST cut off levels: S. agalactiae: $\leq 1 \mu \mathrm{g} /$ 
$\mathrm{ml} ;>1-\leq 2 \mu \mathrm{g} / \mathrm{ml} ;>2 \mu \mathrm{g} / \mathrm{ml}$, E. faecalis: $<0.03 \mu \mathrm{g} /$ $\mathrm{ml} ; \geq 0.03 \mu \mathrm{g} / \mathrm{ml}-\leq 1 \mu \mathrm{g} / \mathrm{ml},>1 \mu \mathrm{g} / \mathrm{ml}$. For mefloquine the threshold of drug resistance was set considering available pharmacokinetic data in human patients and published in vitro inhibitory concentrations against Plasmodium falciparum [18-24]. Thus, the threshold for drug resistance was $0.265 \mu \mathrm{g} / \mathrm{ml}$ for mefloquine.

\section{Results}

All bacterial isolates were sub-cultured after thawing prior to susceptibility assays $(\mathrm{n}=34)$. Median MIC values of SP against Gram-positive bacteria were as follows: $S$. aureus $16 \mu \mathrm{g} / \mathrm{ml}$, S. agalactiae $24 \mu \mathrm{g} / \mathrm{ml}$, S. pneumoniae $4 \mu \mathrm{g} / \mathrm{ml}$, and E. faecalis $12 \mu \mathrm{g} / \mathrm{ml}$ (Table 1, Table 2 and Additional File 1). Median MICs were considerably higher for $N$. gonorrhoeae and E. coli $(256 \mu \mathrm{g} / \mathrm{ml}$ and $128 \mu \mathrm{g} / \mathrm{ml}$, respectively). SP showed high or intermediate activity against all tested Gram-positive bacteria, whereas E. coli and $N$. gonorrhoeae were classified as resistant to SP.

A total of 34 bacterial isolates were evaluated for their in vitro drug susceptibility against mefloquine (Table 1 , Table 2 and Additional File 1). The observed MIC of mefloquine was $16 \mu \mathrm{g} / \mathrm{ml}$ in all tested $S$. aureus and E. faecalis isolates. Similarly growth of $S$. agalactiae was completely inhibited at $16 \mu \mathrm{g} / \mathrm{ml}$ except for one isolate with a MIC of $32 \mu \mathrm{g} / \mathrm{ml}$. The MIC of mefloquine against pneumococci and $N$. gonorrhoeae varied between 0.03 $0.06 \mu \mathrm{g} / \mathrm{ml}$ and $4-16 \mu \mathrm{g} / \mathrm{ml}$, respectively. Based on the observed MIC values S. pneumonia was classified as sensitive, S. aureus, S. agalactiae, E. faecalis, and $N$. gonorrhoeae, and E. coli (Median MIC $128 \mu \mathrm{g} / \mathrm{ml}$ ) as resistant to the in vitro activity of mefloquine.
Table 2 Summary of in vitro anti-bacterial activity of sulphadoxine-pyrimethamine, mefloquine, and azithromycin

\begin{tabular}{lccc}
\hline & $\begin{array}{c}\text { Sulphadoxine/ } \\
\text { Pyrimethamine }\end{array}$ & Mefloquine & Azithromycin \\
\hline S. aureus & + & - & + \\
S. agalactiae & $\sim$ & - & + \\
S. pneumoniae & + & + & + \\
E. faecalis & $\sim$ & - & $\sim /-$ \\
N. gonorrhoeae & - & - & + \\
E. coli & - & - & $\sim$ \\
\hline
\end{tabular}

- Insufficient in vitro activity; intermediate in vitro activity; + good in vitro activity.

Median MIC values of azithromycin were $0.5 \mu \mathrm{g} / \mathrm{ml}$, $0.06 \mu \mathrm{g} / \mathrm{ml}, 0.01 \mu \mathrm{g} / \mathrm{ml}$ and $0.01 \mu \mathrm{g} / \mathrm{ml}$ against $S$. aureus, $S$. agalactiae, S. pneumonia, and $N$. gonorrhoeae, respectively (Table 1, Table 2 and Additional File 1). Activity against E. coli (median MIC $4 \mu \mathrm{g} / \mathrm{ml}$ ) and E. faecalis (median MIC $4 \mathrm{mg} / \mathrm{ml}$ ) was considerably weaker. Neisseria gonorrhoeae and all Gram-positive bacteria except for E. faecalis -were classified as being sensitive to azithromycin. Escherichia coli strains showed intermediate drug susceptibility against azithromycin in vitro.

\section{Discussion}

This in vitro drug susceptibility study showed a broad spectrum of anti-bacterial activity of SP against Grampositive and low activity against Gram-negative bacteria. Among the two currently proposed alternative drugs for IPTp - mefloquine and azithromycin - the latter shows

Table 1 Median minimal inhibitory concentrations (MIC) of anti-malarials against selected Gram-positive and Gramnegative bacteria

\begin{tabular}{|c|c|c|c|}
\hline \multirow[t]{2}{*}{ Microorganisms } & \multicolumn{3}{|c|}{ Median Minimal Inhibitory Concentration $(\mu \mathrm{g} / \mathrm{ml})$} \\
\hline & Sulphadoxine/Pyrimethamine & Mefloquine & Azithromycin \\
\hline S. aureus $(n=5)$ & 16 & 16 & 0.5 \\
\hline S. pneumoniae $(\mathrm{n}=5$ ) & 4 & 0.06 & 0.01 \\
\hline E. faecalis $(n=5)$ & 12 & 16 & 4 \\
\hline N. gonorrhoeae $(n=10)$ & 256 & 8 & 0.01 \\
\hline E. coli $(n=5)$ & 128 & 128 & 4 \\
\hline
\end{tabular}

Thresholds for drug resistance:

Mefloquine: sensitive: $\leq 0.265 \mu \mathrm{g} / \mathrm{ml}$

Sulphadoxine/Pyrimethamine (threshold based on fractional pyrimethamine concentration in 1:20 combination): sensitive, intermediate, resistant

S. aureus and E. coli: $\leq 2 \mu \mathrm{g} / \mathrm{ml} ;>2-<4 \mu \mathrm{g} / \mathrm{ml} ; \geq 4 \mu \mathrm{g} / \mathrm{ml}$,

S. pneumonia: $\leq 0.5 \mu \mathrm{g} / \mathrm{ml} ;>0.5-<4 \mu \mathrm{g} / \mathrm{ml} ; \geq 4 \mu \mathrm{g} / \mathrm{ml}$,

S. agalactiae: $\leq 1 \mu \mathrm{g} / \mathrm{ml} ;>1-\leq 2 \mu \mathrm{g} / \mathrm{ml} ;>2 \mu \mathrm{g} / \mathrm{ml}$,

E. faecalis: $\otimes 0.03 \mu \mathrm{g} / \mathrm{ml} ; \geq 0.03-\leq 1 \mu \mathrm{g} / \mathrm{ml} ;>1 \mu \mathrm{g} / \mathrm{ml}$. Azithromycin: sensitive, intermediate, resistant

S. aureus; $E$. coli and $E$. faecalis $\leq 2 \mu \mathrm{g} / \mathrm{ml},>2-<8 \mu \mathrm{g} / \mathrm{ml}, \geq 8 \mu \mathrm{g} / \mathrm{ml}$;

S. pneumonia and S. agalactiae $\leq 0.5 \mu \mathrm{g} / \mathrm{ml},>0.5-<2 \mu \mathrm{g} / \mathrm{ml}, \geq 2 \mu \mathrm{g} / \mathrm{ml}$;

N. gonorrhoeae $\leq 0.25 \mu \mathrm{g} / \mathrm{ml} ;>0.25 \mu \mathrm{g} / \mathrm{ml}-\leq 0.5 \mu \mathrm{g} / \mathrm{ml} ;>0.5 \mu \mathrm{g} / \mathrm{ml}$ 
an even broader anti-bacterial spectrum of activity as SP with good activity against $N$. gonorrhoeae. Interestingly, previous reports indicate in vitro activity of mefloquine against E. coli $[25,26]$. The present study, however, demonstrated high activity of mefloquine against pneumococci and low activity against all other bacteria. Whether these findings similarly translate into clinically relevant in vivo activity of mefloquine needs further investigation since no validated resistance thresholds are available for mefloquine.

This evaluation of the anti-microbial activity of antimalarials in vitro may provide the basis for further clinical evaluation. Based on our data a clinically important effect on concurrent infectious diseases in pregnant women may be anticipated for SP and azithromycin and to a lesser extent for mefloquine. Previous data show that bacterial infections including sexually transmitted diseases, pneumococcal infections, and S. agalactiae colonisation contribute significantly to adverse pregnancy outcome in sub-Saharan Africa [27]. Similarly, there is evidence for significant improvement of maternal and child health by routine administration of appropriate anti-microbial drugs during pregnancy [28]. Given that urinary and genital tract infections are an important cause for premature delivery, it may be speculated that the routine administration of SP and azithromycin for IPTp may confer a reduction in the rate of prematurity due to the antibiotic effect. Similarly the potential for eradication of vaginal S. agalactiae colonization by IPTp with SP or azithromycin might prevent cases of neonatal sepsis. However, caution must be employed by the extrapolation of data on in vitro activity of drugs to anticipated in vivo efficacy. Clinical efficacy will ultimately depend - besides the intrinsic anti-bacterial activity as assessed in this study - on drug absorption, drug concentrations at the target sites, half-lives of drugs, and the local pattern of drug resistant pathogens. Additionally a limitation of our study lies in the absence of validated thresholds for the in vitro activity of SP and mefloquine. The proposed levels are extrapolated from antifolate antibiotics or based on thresholds of in vitro activity against P. falciparum and need further clinical validation [17].

The next generation of IPTp drugs will be chosen based on pharmacodynamic properties and its safety, tolerability, simplicity of administration, and cost. Based on the hypothesis of a collateral health benefit by the administration of anti-malarials with activity against relevant bacterial pathogens, it may seem desirable to choose the next IPTp drug based on both its antimalarial and anti-bacterial pharmacodynamic properties. Whether such an approach is justified or not is however to date unknown. Whereas it may look attractive to simultaneously treat concomitant and potentially deleterious bacterial infections by routine administration of anti-malarials, this strategy may also prove hazardous. Large-scale use of drugs with anti-bacterial activity may speed up the process of selection of drug resistant bacterial isolates. Interestingly, there is evidence for the development of antibiotic drug resistance by crossresistance with anti-malarial drugs [29]. Epidemiologic evidence linking the development of quinolone resistant Gram-negative bacteria with large-scale use of chloroquine and the recent development and spread of quinolone resistant $N$. gonorrhoeae strains are illustrative examples for this phenomenon [30]. In this context the potential selection of drug resistance against anti-folate and macrolide antibiotics by the use of SP and azithromycin as IPTp is of particular concern. The threat of promoting drug resistance against commonly used antibiotics is particularly worrying for sub-Saharan Africa where microbiologic analysis of infections is rarely performed and alternative antibiotics for drug resistant pathogens are often not affordable.

\section{Conclusion}

These data indicate that sulphadoxine-pyrimethamine and azithromycin are active against a broad spectrum of bacterial pathogens whereas mefloquine's activity is restricted to pneumococci. Whether the choice of a second generation IPTp drug with broad or narrow antibacterial spectrum is favourable for maternal and foetal health, is currently unknown. Further clinical trials evaluating the efficacy of IPTp against concomitant bacterial infections and the impact of their large scale use on the development and spread of antibiotic drug resistance are therefore necessary to allow an informed decision on the next IPTp drug for Africa.

\section{Additional material}

Additional file 1: Minimal inhibitory concentrations (MIC) of antimalarials against selected Gram positive and Gram negative bacteria. Listing of minimal inhibitory concentrations of all isolates.

\section{Acknowledgements}

We are grateful for excellent technical assistance by Ing. W. Schmid and MTA H-M. Winkler.

\section{Author details}

${ }^{1}$ Institute for Tropical Medicine, University of Tübingen, Tübingen, Germany ${ }^{2}$ Medical Research Unit, Albert Schweitzer Hospital, Lambaréné, Gabon.

${ }^{3}$ Department of Parasitology and Mycology, University of Health Sciences, Libreville, Gabon. ${ }^{4}$ Department of Laboratory Medicine, Division of Clinical Microbiology, Medical University of Vienna, Vienna, Austria. ${ }^{5}$ Department of Medicine I, Division of Infectious Diseases and Tropical Medicine, Medical University of Vienna, Vienna, Austria.

\section{Authors' contributions}

MR and GMN developed the concept and design of the study, were responsible for data analysis, and drafting of the manuscript. MC participated in study design, was responsible for the collection of data, and contributed 
to data analysis, interpretation, and drafting of the manuscript. AM participated in study design, data analysis, and critical review of the manuscript. All authors read and approved the final manuscript.

\section{Competing interests}

The authors declare that they have no competing interests.

Received: 17 April 2010 Accepted: 29 October 2010

Published: 29 October 2010

\section{References}

1. Brabin B: The risk and severity of malaria in pregnant women. Applied Field Research in Malaria Reports. Special Programme for Research and Training in Tropical Diseases World Health Organisation 1991, vol. TDR/ FIELDMAL/1.

2. Brabin BJ: An analysis of malaria in pregnancy in Africa. Bull World Health Organ 1983, 61:1005-1016.

3. McGregor IA: Epidemiology, malaria and pregnancy. Am J Trop Med Hyg 1984, 33:517-525.

4. McGregor IA, Wilson ME, Billewicz WZ: Malaria infection of the placenta in The Gambia, West Africa; its incidence and relationship to stillbirth birthweight and placental weight. Trans R Soc Trop Med Hyg 1983, 77:232-244.

5. Gilles HM, Lawson JB, Sibelas M, Voller A, Allan N: Malaria, anaemia and pregnancy. Ann Trop Med Parasitol 1969, 63:245-263.

6. Ramharter M, Grobusch MP, Kiessling G, Adegnika AA, Moller U, Agnandji ST, Kramer M, Schwarz N, Kun JF, Oyakhirome S, Issifou S, Borrmann S, Lell B, Mordmüller B, Kremsner PG: Clinical and parasitological characteristics of puerperal malaria. J Infect Dis 2005, 191:1005-1009.

7. Desai M, Kuile FOt, Nosten F, McGready R, Asamoa K, Brabin B, Newman RD: Epidemiology and burden of malaria in pregnancy. Lancet Infect Dis 2007, 7:93-104.

8. Ramharter M, Schuster K, Bouyou-Akotet MK, Adegnika AA, Schmits K, Mombo-Ngoma G, Agnandji ST, Nemeth J, Afene SN, Issifou S, Onnas IN, Kombila M, Kremsner PG: Malaria in pregnancy before and after the implementation of a national IPTp program in Gabon. Am J Trop Med Hyg 2007, 77:418-422.

9. WHO: A strategic Framework for Malaria Preventation and Control During Pregnancy in the Africa Region World Health Organization Regional Office for Africa; 2004, AFR/MAL/04/01.

10. Briand V, Cottrell G, Massougbodji A, Cot M: Intermittent preventive treatment for the prevention of malaria during pregnancy in high transmission areas. Malar J 2007, 6:160

11. Briand V, Bottero J, Noel H, Masse V, Cordel H, Guerra J, Kossou H, Fayomi B, Ayemonna P, Fievet N, et al: Intermittent treatment for the prevention of malaria during pregnancy in Benin: a randomized, openlabel equivalence trial comparing sulfadoxine-pyrimethamine with mefloquine. J Infect Dis 2009, 200:991-1001.

12. Clerk CA, Bruce J, Affipunguh PK, Mensah N, Hodgson A, Greenwood B, Chandramohan D: A randomized, controlled trial of intermittent preventive treatment with sulfadoxine-pyrimethamine, amodiaquine, or the combination in pregnant women in Ghana. J Infect Dis 2008, 198:1202-1211.

13. Mehaffey PC, Barrett MS, Putnam SD, Jones RN: Antigonococcal activity of 11 drugs used for therapy or prophylaxis of malaria. Diagn Microbiol Infect Dis 1995, 23:11-13.

14. Wormser GP, Keusch GT, Heel RC: Co-trimoxazole (trimethoprimsulfamethoxazole): an updated review of its antibacterial activity and clinical efficacy. Drugs 1982, 24:459-518.

15. Chico RM, Pittrof R, Greenwood B, Chandramohan D: Azithromycinchloroquine and the intermittent preventive treatment of malaria in pregnancy. Malar J 2008, 7:255.

16. U.S Food and Drug Administration (FDA): Zithromax ${ }^{\oplus}$ (Azithromycin tablets and azithromycin for oral suspension). [http://www.accessdata.fda. gov/drugsatfda_docs/label/2009/050693s014,050730s021lbl.pdf], accessed on 16.08.2010.

17. Cartwright CP, Stock F, Gill VJ: Improved enrichment broth for cultivation of fastidious organisms. J Clin Microbiol 1994, 32:1825-1826.

18. Ramharter M, Kurth FM, Belard S, Bouyou-Akotet MK, Mamfoumbi MM Agnandji ST, Missinou MA, Adegnika AA, Issifou S, Cambon N, Heidecker JL, Kombila M, Kremsner PG: Pharmacokinetics of two paediatric artesunate mefloquine drug formulations in the treatment of uncomplicated falciparum malaria in Gabon. J Antimicrob Chemother 2007, 60:1091-1096.

19. Bustos DG, Lazaro JE, Gay F, Pottier A, Laracas CJ, Traore B, Diquet B: Pharmacokinetics of sequential and simultaneous treatment with the combination chloroquine and sulfadoxine-pyrimethamine in acute uncomplicated Plasmodium falciparum malaria in the Philippines. Trop Med Int Health 2002, 7:584-591.

20. Ramharter M, Noedl H, Thimasarn K, Wiedermann G, Wernsdorfer G, Wernsdorfer WH: In vitro activity of tafenoquine alone and in combination with artemisinin against Plasmodium falciparum. Am J Trop Med Hyg 2002, 67:39-43.

21. Ramharter M, Noedl H, Winkler H, Graninger W, Wernsdorfer WH, Kremsner $\mathrm{PG}$, Winkler $\mathrm{S}$ : In vitro activity and interaction of clindamycin combined with dihydroartemisinin against Plasmodium falciparum. Antimicrob Agents Chemother 2003, 47:3494-3499.

22. Ramharter M, Wernsdorfer WH, Kremsner PG: In vitro activity of quinolines against Plasmodium falciparum in Gabon. Acta Trop 2004, 90:55-60.

23. WHO: In vitro Micro-Test (Mark III) for the assessment of the response of Plasmodium falciparum to chloroquine, mefloquine, quinine, amodiaquine, sulfadoxine/pyrimethamine and artemisinin: Instructions for use of the in vitro micro-test kit 2001, Ctd/Mal/97.20 (Rev. 2)

24. Winstanley PA: Treatment and prevention of falciparum malaria in Africa. J R Coll Physicians Lond 1992, 26:445-449.

25. Bromke BJ, McGinn M: In vitro susceptibility of selected non-protozoa to mefloquine. Acta Microbiol Hung 1993, 40:387-389.

26. Brown RE, Stancato FA, Wolfe AD: The effects of mefloquine on Escherichia coli. Life Sci 1979, 25:1857-1864.

27. Mullick S, Watson-Jones $D$, Beksinska M, Mabey D: Sexually transmitted infections in pregnancy: prevalence, impact on pregnancy outcomes, and approach to treatment in developing countries. Sex Transm Infect 2005, 81:294-302.

28. Gray RH, Wabwire-Mangen F, Kigozi G, Sewankambo NK, Serwadda D, Moulton LH, Quinn TC, O'Brien KL, Meehan M, Abramowsky C, Robb M, Wawer MJ: Randomized trial of presumptive sexually transmitted disease therapy during pregnancy in Rakai, Uganda. Am J Obstet Gynecol 2001, 185:1209-1217.

29. Davidson RJ, Davis I, Willey BM, Rizg K, Bolotin S, Porter V, Polsky J, Daneman N, McGeer A, Yang P, Scolnik D, Rowsell R, Imas O, Silverman MS: Antimalarial therapy selection for quinolone resistance among Escherichia coli in the absence of quinolone exposure, in tropical South America. Plos One 2008, 3:e2727.

30. Knapp JS, Fox KK, Trees DL, Whittington WL: Fluoroquinolone resistance in Neisseria gonorrhoeae. Emerg Infect Dis 1997, 3:33-39.

doi:10.1186/1475-2875-9-303

Cite this article as: Capan et al: Anti-bacterial activity of intermittent preventive treatment of malaria in pregnancy: comparative in vitro study of sulphadoxine-pyrimethamine, mefloquine, and azithromycin. Malaria Journal 2010 9:303.

\section{Submit your next manuscript to BioMed Central and take full advantage of:}

- Convenient online submission

- Thorough peer review

- No space constraints or color figure charges

- Immediate publication on acceptance

- Inclusion in PubMed, CAS, Scopus and Google Scholar

- Research which is freely available for redistribution 